\title{
A Jesuit Utopian Project on Behalf of the Conversos: Fernando de Valdés and the Statutes of Purity of Blood (1632)
}

\author{
Juan Hernández Franco \\ University of Murcia, History Department, Murcia, Spain \\ jhf@um.es \\ Pablo Ortega-del-Cerro \\ Consejo Superior de Investigaciones Científicas, Madrid, Spain \\ pablo.ortega@cchs.csic.es
}

\begin{abstract}
In 1632, the Jesuit Father Fernando de Valdés (1584-1642) completed his Memorial para quitar o limitar Estatutos de limpieza. In this treatise, Valdés sought to abolish the statutes of purity of blood and reassess the longstanding division between New and Old Christians. Additionally, the Memorial offers a novel portrait of Castilian conversos. According to Valdés, New Christians were singled out for discrimination, despite their evident virtues as sincere Catholics and faithful subjects. He did not seek to break the existing social order, but rather to offer a profound critique of the Old Christian hegemony. Ultimately, Valdés proposed an essentially utopian model of society built on personal merits and behavior, rather than blood-based and inherited privileges. This article seeks to study this Memorial in the context of the debate about the statutes of purity of blood and as an important element of that debate within the Society of Jesus.
\end{abstract}

\section{Keywords}

Jesuits - Fernando de Valdés - conversos - Spain - purity-of-blood - utopia meritocracy 


\section{Introduction $^{1}$}

From the mid-fifteenth century onward, several Castilian institutions promulgated statutes of purity of blood in order to exclude the descendants of converts from their ranks. During the sixteenth century, the concept of purity of blood spread and became an important issue within the Spanish monarchy, stimulating a great deal of written debate. The discussion reached a crescendo when the archbishop of Toledo, Juan Martínez Silíceo (1486-1557), issued a purity of blood edict at the council of his cathedral. In 1555, the monarchy and the papacy ratified this edict, establishing the basis for the juridical enforcement of purity of blood. Silíceo's edict provoked a division within Castilian society: on the one hand, the vast majority embraced this ideology and supported the maintenance of the social stratification that it upheld; on the other, some rejected this race- and lineage-based discrimination.

Ignatius de Loyola (c.1491-1556) was one of the most representative voices for accepting converso candidates to the order. In his view, conversos practiced Christianity much like Old Christians, and they were clearly predisposed to the "universal good." The Constitutions of the Society of Jesus did not exclude New Christians from the order, and there was no reference to conversos in the list of impediments. Even several years later, Ignatius retained his position against the statutes, resisting any sort of agreement with Archbishop Silíceo. ${ }^{3}$ Other Spanish members of the Society, such as Juan Alfonso de Polanco $(1517-76)$ and Alfonso Salmerón (1515-85), unlike the Portuguese Jesuits, went further and affirmatively argued against the statutes, recalling the inclusive policies that the order had maintained, at least until the end of the generalship of Francisco de Borja (1565-72).

Purity of blood never attained the status of generally applicable law in the Spanish monarchy; nevertheless, during the reign of Philip II (r.1556-98), tensions arose around the question of its implementation. The intensification

1 This work was supported by Project "Entornos sociales de cambio: Nuevas solidaridades y ruptura de jerarquías (siglos XVI-XX)," HAR2017-84226-C6-1-P, Ministry of Science, Innovations and Universities, Spain.

2 Eusebio Rey, "San Ignacio de Loyola y el problema de los 'cristianos nuevos," Razón y fe 153 (1956): 173-204; James Reites, "St. Ignatius and Jews," Studies in the Spirituality of the Jesuits 13, no. 4 (1981): 1-48.

3 Francisco de Borja Medina, "Ignacio de Loyola y la limpieza de sangre," in Ignacio de Loyolay su tiempo, ed. Juan Plazaola (Bilbao: Mensajero, 1992), 579-615; Medina, "Ignacio de Loyola y los judíos," Anuario del Instituto Ignacio de Loyola 4 (1997): 37-63; Robert A. Maryks, "Ignatius of Loyola and the Converso Question," in A Companion to Ignatius of Loyola: Life, Writings, Spirituality, Influence, ed. Robert A. Maryks (Leiden: Brill, 2014), 85-102. 
of the debate about purity of blood coincided with the monarchy's declining enthusiasm for such edicts. Support began to wane when Cardinal Gaspar de Quiroga (1512-94), inquisitor general (1573-94) and archbishop of Toledo (1577-94), became the "great patron" of the court between 1573 and $1586 .{ }^{4}$ Even Philip II himself considered reforming the statutes during the last decade of his reign, a viewpoint that would attract such prestigious religious personalities as the Franciscan Gaspar de Uceda (c.1520-88), the Dominican Agustín Salucio (1523-16o1), and the Augustinian Luis de León (1527-91).

In the Society of Jesus, however, discrimination for reasons of lineage and race grew steadily after the election of Everard Mercurian (1514-80; in office $1573-80$ ), especially after the emergence of an increasingly powerful Italian-Portuguese and anti-Spanish group. For decades, there was an intense debate on this issue within the order. ${ }^{5}$ Finally, the Fifth General Congregation (1593-94) ended the traditionally inclusive policy of "union of hearts" by excluding any candidate with a converso lineage from the order. ${ }^{6}$ The Jesuit institution of the statutes of purity of blood was not well-received by members of the assistancy of Spain. Leading Jesuits such as Diego de Guzmán (c.1522-16o6), Pedro de Ribadeneyra (1526-1611), García Girón de Alarcón (1534-97), Juan de Mariana (1536-1624), ${ }^{7}$ and Ignacio de las Casas (1550-16o8) opposed discrimination for reasons of blood - the latter in the case of descendants of Muslims. ${ }^{8}$

The main proposal to limit or reform the statutes at the end of the sixteenth century was made by the Dominican Father Salucio. Although Salucio's proposal was ultimately rejected, his discourse had a broad impact during the reign of Philip III (r.1598-1621), including among Jesuits a minority of whom

4 Henar Pizarro Llorente, Un gran patrón en la corte de Felipe II: Don Gaspar de Quiroga (Madrid: Universidad Pontificia de Comillas, 2004), 389-508.

5 Robert A. Maryks, The Jesuit Order as a Synagogue of Jews: Jesuits of Jewish Ancestry and Purity-of-Blood Laws in the Early Society of Jesus (Leiden: Brill, 2009), 123-41; Mario Prades Villar, "Pedro de Ribadeneyra escribe a Claudio Aquaviva: Un episodio de la polémica jesuita sobre los estatutos de pureza de sangre," Ingenium: Revista de historia del pensamiento moderno 6 (2012): 125-45.

6 Francisco de Borja Medina, "La quiebra de universalismo de la unión de ánimos," in "Ite inflammate omnia": Selected Historical Papers from Conferences Held at Loyola and Rome in 2006, ed. Thomas M. McCoog (Rome: Institutum Historicum Societatis Iesu, 2010), 321-44; Maryks, Jesuit Order as a Synagogue of Jews, 42-9o; Thomas M. Cohen, "Jesuits and New Christians: The Contested Legacy of St. Ignatius," Studies in the Spirituality of Jesuits 42, no. 3 (2010): 1-6.

7 Maryks, Jesuit Order as a Synagogue of Jews, 182-213.

8 Youssef El Alaoui, Jésuites, morisques et indiens: Étude comparative des méthodes d'évangélisation de la Compagnie de Jésus d'après les traités de José de Acosta (1588) et d'Ignacio de las Casas (1605-1607) (Paris: Éditions Honoré Champion, 2006). 
were eventually persuaded of the merit of amending the statutes. These authors tried to make their voices heard in a society that was obsessed with purity of blood and took pride in Old Christian status. While Spanish society had turned "blood without stain" into a key badge of distinction, the rumbling dissent gradually became louder. The most illustrative example of dissent during the reign of Philip III is the Memorial of Diego Sánchez de Vargas (fl.160os), a Portuguese converso. He proposed a drastic restriction of the statutes and advanced a different attitude toward Portuguese converts:

In the current state of Spain, relating to the faith of the heretics, Jews and Moors, today is different from the time the statutes were promulgated. Then, they had a questionable faith, but now they are true and safe Christians [...]; and for these reasons I have decided to present this supplication, in which I try to prove that it is advisable to limit the statutes of purity of blood. ${ }^{9}$

The Memorial was sent to the king's favorite, Francisco Gómez de Sandoval y Rojas, 1st duke of Lerma (1553-1625), and the inquisitor general, Bernardino de Rojas (1546-1618). The intermediary was the Jesuit Juan de Montemayor (1549-1641), provincial of Castile, who was tasked with determining whether or not to publish the piece. Probably influenced by Ignatius's attitude that New Christians were true Christians and sought the "universal good," he resolved to publish. The social contention caused by the statutes of purity of blood, which had become a serious problem for the Spanish monarchy, ${ }^{10}$ may have been an additional motivation for publishing the work. The publication was one of the ways the Spanish Jesuits promoted their resistance to the statutes; eventually, it prompted a revision of the statute of purity of blood in the Sixth General Congregation (1608). This revision somewhat lessened the harshness of the lineage decree. Jesuit candidates had to demonstrate that they had been Old Christians for five generations, but through a more discreet and less intrusive means of demonstration ("diligent," "secret," and "prudent").

9 Archivo Histórico Nacional (AHN), Órdenes Militares, 1320 , fol. $178^{\mathrm{r}}$. In the margin there is a note: "This paper was printed." Uriarte thought that Juan de Montemayor was the author of this supplication. See José Eugenio de Uriarte, Catálogo razonado de obras anónimas y seudónimos de autores de la Compañía de Jesús (Madrid: Sucesores de Rivaneyra, 1904-1916), 1:36.

10 Antonio Domínguez Ortiz, Los judeoconversos en la España Moderna (Madrid: Mapfre, 1992), 73; Israel S. Révah, "Gil González de Ávila et les statuts de pureté de sang," in Studia hispanica in honorem Rafael Lapesa (Madrid: Gredos, 1974), 493-518. 
Beginning in the 1620s, under Philip IV's rule (1621-65), several sectors within the court aimed to expand the discussion. They insisted that the statutes harmed the monarchy because purity-of-blood notions erected divisions- "walls" - in society. They particularly criticized automatic exclusion from major posts in influential institutions on the basis of minor doubts about lineage. Thus, the statutes of purity of blood created a social separation in the heart of the primarily Christian republic. This was one of the factors that prompted the king's favorite, Gaspar de Guzmán y Pimentel, 1st duke of Sanlúcar, 3 rd count of Olivares (1587-1645), to endorse an overarching policy of reform. The minority who favored the reform and a limiting of the statutes was comprised of the administrative and religious elites, who at the same time supported the reformist political project of the monarchy.

The more pragmatic among this minority proposed limiting the number of generations to be examined in the proofs of purity of blood, while only a few went beyond this notion. This more radical group dared request that the king abrogate or suppress the statutes altogether. The Jesuit Fernando de Valdés was the most prominent figure to articulate this idea, which he did in his Memorial in $1632 .{ }^{11}$ In this work, he proposed to consider conversos as sincere Christians in accordance with their behavior. In addition, he posited, they were loyal and useful for a monarchy living in the midst of a severe economic and social crisis. ${ }^{12}$

\section{Fernando de Valdés and the Statutes}

The Spanish monarchy was experiencing difficult times. Its rise as a global power in the sixteenth century was cut short by its collapse. During the first part of the reign of Philip IV, especially throughout the administration of his favorite, the count-duke of Olivares, a group of Spanish Jesuits enjoyed power from backstage. ${ }^{13}$ They favored and participated in Olivares's project, the campaign to preserve Spain "as the dominant world power" and find "the

11 There are two writings produced at the same time, which requested the suppression of the statutes: "Memorial de algunas razones para quitar en todo o en parte los estatutos de limpieza," AHN, Órdenes Militares, 1320 , fols. $77^{\mathrm{r}}-119^{\mathrm{r}}$; and "Saber si es justo extinguir el estatuto de limpieza o si conviene que se modere," AHn, Órdenes Militares, 1320, fols. $192^{\mathrm{v}}-212^{\mathrm{r}}$.

12 For many years, this writing was ignored by historiography. Only Henry Kamen mentioned this source. See Henry Kamen, "Una crisis de conciencia en la edad de oro en España: La Inquisición contra Limpieza de Sangre," Bulletin hispanique 88 (1986): 352-54.

13 Julián J. Lozano Navarro, La Compañía de Jesús y el poder en la España de los Austrias (Madrid: Cátedra, 2005), 119-65. 
fair answers that were necessary for the defiance of decadence."14 This group included important figures such as Hernando de Salazar (1577-1646), the countduke's eminence grise; Jerónimo de Florencia (1565-1633); Gonzalo Albornoz (c.1578-?); Francisco Pimentel (c.1588-?);15 Diego de Alarcón (1585-1634); Juan Bautista Poza (1588-1659);16 Francisco Aguado (1571-1654); Juan Martínez de Ripalda (1594-1648); and, in particular, Fernando de Valdés (1584-1642), the subject of this study.

Valdés entered the Society of Jesus in $1604 .{ }^{17}$ Initially, he taught theology, and from 1625 to 1637 , he served as rector of the Jesuit community in Madrid. From 1637 to 1640, Valdés served as the provincial of Toledo, one of the four Spanish Jesuit provinces. Finally, he became the procurator of the same province, serving in this capacity until his death. ${ }^{18}$ During the 163 os, Valdés tried to improve the finances of the Jesuit province of Toledo, ${ }^{19}$ and in the provincial congregation (1639), he set about correcting various irregularities in that sphere. ${ }^{20}$ Additionally, he developed a plan for the Imperial College of Madrid and visited it regularly. ${ }^{21} \mathrm{He}$ also mediated between superiors of the order and Juan Eusebio Nieremberg (1595-1658) in order to obtain a license to publish Nieremberg's work, Varones ilustres. ${ }^{22}$ Valdés corresponded with Juan Bautista

14 John H. Elliott, The Count-Duke of Olivares: The Statesman in an Age of Decline (New Haven: Yale University Press, 1986), ix; Elliott, History in the Making (New Haven: Yale University Press, 2012), 114-35.

15 Lozano Navarro, Compañía de Jesús, 199-216.

16 Juan I. Pulido Serrano, "Inquisición, dominicos y jesuitas en el siglo XVII," in Praedicatores, inquisitores: I domenicani e l'Inquisizione romana, ed. Carlo Longo (Rome: Istituto Storico Domenicano, 2006), 283-307; Doris Moreno and Manuel Peña, "Juan Bautista Poza y la censura," in Riti de passaggio, storie di giustizia, ed. Adriano Prosperi (Pisa: Edizioni della Normale, 2011), 159-69.

17 Archivum Romanum Societatis Iesu (ARSI), Tolet. 47, fol. 22v. Josephus Fejér, Defuncti secundi saeculi Societatis Jesu, 1641-1770, 5 vols. (Rome: Curia Generalitia S.J., Institutum Historicum S.J., 1985-9o), 5:232.

18 Carlos Sommervogel, Bibliothèque de la Compagnie de Jésus, 12 vols. (Brussels: GrandmontDonders, 1898), 8:376.

19 Archivo Municipal de Talavera de la Reina, Colegio de la Compañía (1511-1816), 13, no. 16, Madrid, 1638.

20 Real Academia de la Historia (RAH), Colección Jesuitas, 9-7259; Antonio Astrain, Historia de la Compañía de Jesús en la Asistencia de España, 7 vols. (Madrid: Sucesores de Rivadeneyra, 1916), 5:262.

21 Bernabé Bartolomé Martínez, "Educación y humanidades clásicas en el Colegio Imperial de Madrid durante el siglo XVII," Bulletin hispanique 97, no. 1 (1995): 109-55.

22 ARSI, Tolet. 10, fol. $3^{1}$. Quoted by Hugues Didier, Vida y pensamiento de Juan E. Nieremberg (Madrid: Universidad Pontificia de Salamanca, 1976), 64. On Nieremberg's literary activities, see D. Scott Hendrickson, Jesuit Polymath of Madrid: The Literary Enterprise of Juan Eusebio Nieremberg (1595-1658) (Leiden: Brill, 2015). 
Poza (1588-1659) and wrote about Juan de Montalvo (1572-1639), who was his predecessor in the province of Toledo. ${ }^{23}$

The work we will examine is entitled Memorial de Fernando de Valdés, rector del Nouiciado de la Compañia de Iesvs desta villa de Madrid y Calificador del Supremo Consejo de la Santa y General Inquisicion para quitar, o limitar, estatutos de limpieza: pone a V. Magestad en consideración lo siguiente (Memorial of Fernando de Valdés [...] to abolish or restrict the statutes of purity of blood). ${ }^{24}$ This document was completed in Madrid on October 15, 1632, but was not formally published. Although printed, there are no indications of the name of the printing press, and it did not follow the regular bureaucratic channels of publication. This means that its circulation and reception was limited to an elite minority - primarily the king, to whom the Memorial was dedicated, along with members of the court. ${ }^{25}$ Comprising thirty-two double-sided pages and divided into seven chapters, the structure of this document is complex and convoluted, with myriad references to the Holy Scriptures, the fathers of the church, and various saints, pontiffs, and philosophers. Valdés was well acquainted with and made use of the literature arguing for the integration of the conversos (e.g. Alonso de Oropesa [?-1468], Agustín Salucio [1523-16o1], Pedro de Portocarrero [1545-160o], Fernando Niño de Guevara [1541-16o9], Bernardo de Sandoval [1546-1618], or Andrés Pacheco [1550-1626]) as well as works that supported the statutes of purity of blood (e.g. Juan Martínez Silíceo [1486-1557] and Diego de Simancas [1513-83]).

The Memorial was essentially a plea for the revocation of the statutes of purity of blood and the elimination of discrimination based on lineage. Arguing persuasively in chapters three and four of the work, Valdés set forth the religious and theological principles that seemed to oppose the statutes. As he was fully aware of the difficulty of achieving his ultimate goal of revocation, however, he also offered the softer alternative of merely moderating the required proofs of blood purity. His main concern in this regard was removing the impediments that the purity of blood statutes placed in front of potential royal servants at a time when the monarchy desperately needed such useful vassals. Valdés warned against the damage that application of the

23 RAH, Colección Jesuitas, 9/3627, fols. 138 ${ }^{\mathrm{r}}-139^{\mathrm{v}}$; Juan Eusebio Nieremberg and Alonso de Andrade, Varones ilustres en santidad, letras y zelo de las almas de la Compañia de Iesus, 6 vols. (Madrid: Ioseph Fernández de Buendia, 1666), 5:656.

24 AHN, Inquisición, lib. 1240, "Memorial de Fernando de Valdés, rector del nouiciado de la Compañía de Jesús desta villa de Madrid, y calificador del supremo Consejo de la Santa y General Inquisición, para quitar o limitar Estatutos de limpieza," Madrid, 15 de octubre de 1632 [henceforth, Memorial de Fernando de Valdés...].

Kamen, "Una crisis de conciencia," 352. 
statutes caused, including the decline in population growth that resulted from decrease in marriage due to fear of mixing "pure" and "impure" blood; the considerable expense to families incurred by the requirement of purity proofs before marriage; the climate of social conflict, hatred, revenge, and rivalry; and the displacement of merit and virtue by the hazards of birth and blood. He also presented interesting reflections on the personality of the convert, an issue that would require clarification if a true reform was to be implemented.

We believe that Valdés's Memorial must be contextualized within the reformist program that Olivares undertook: the king's favorite tried to reassess the statutes of purity of blood and limit the effect of such discrimination. There were many other attempts at reform, such as the royal decree (pragmática real) on the acts of purity of blood published in 1623, but these ultimately fell by the wayside. ${ }^{26}$ For a brief period, it seemed that the joint action of politicians and intellectuals, led by Olivares, would lead to change, but the changes effected were clearly weaker than the beliefs that defended the pre-eminence of Old Christians. ${ }^{27}$ Valdés's proposal could not be tolerated by a society whose vast majority, as the Jeronimite Jerónimo de la Cruz (fl.1630s) wrote, favored purity of blood criteria and attempted to apply a "rigorous" policy in favor of the statutes. ${ }^{28}$ Valdés belonged to a minority that proposed to reform the statutes, and which had no unified opinion concerning this issue. Some aimed to reform the rigor of the proofs of purity, while others displayed a utopian attitude in their aim to abolish the statutes entirely. Reformers included the Jesuits Salazar and Andrade (1590-1672); the Benedictine Benito de Peñalosa y Mondragón (c.158o-1646) the inquisitors Juan Roco Campofrío (1565-1635) and Diego Serrano de Silva (1578-1630), the arbitrista Jerónimo de Ceballos (1560-1641), and other individuals who maintained anonymity. ${ }^{29}$

Perhaps the most influential figure for Valdés was the renowned Jesuit Francisco Suárez (1548-1617). Known as Doctor Eximius, Suárez, who came from a New Christian family, was an innovative expositor of Thomist theology

26 Roberto López Vela, "Antijudaísmo, pruebas de limpieza y la pragmática de actos positivos de 1623," in Nobleza hispana, nobleza cristiana: La Orden de San Juan de Dios, ed. Manuel Rivero (Madrid: Polifemo, 2009), 823-28.

27 Juan Hernández Franco, "Les intellectuels espagnols du Xviıe siècle face à l'opinion majoritaire de la société vieille-chrétienne," in La pureté de sang en Espagne: Du lignage à la "race," ed. Raphaël Carrasco, Annie Molinié, and Béatrice Perez (Paris: Presses de l'Université Paris-Sorbonne, 2011), 315-38.

28 Jerónimo de la Cruz, Defensa de los y noblezas españolas (Zaragoza: Hospital Real, 1637), 297-98.

29 Juan Hernández Franco, "Síntomas de decadencia y el 'Discurso' de Juan Roco Campofrío (c.1625) sobre la reforma de los estatutos de limpieza," Hispanic Research Journal 15 (2014): 477-91. 
and a famous member of the Salamanca School. While he was writing one of his most important works, De legibus (1613), where he outlined his natural law theory, he also composed De religione (1608-9), in which he elaborated on the lifestyle of religious communities, especially Jesuits. ${ }^{30}$ Suárez endorsed the statutes of purity based on arguments from moral theology, particularly regarding the interpretation of law. ${ }^{31}$ According to the principles of moral theology examined in his latter book, a law can be annulled in two ways: negative or contrarie. The latter case happens when observance of the law is harmful, injurious, and not easily implemented. Paradoxically, Valdés grounded the legitimacy of abrogating or limiting laws of purity of blood upon Suárez's own criteria of invalidation.

When the Memorial was completed in autumn 1632, Valdés remarked that he had been motivated to write the treatise by what he called "my religious profession." He confessed that his opinions on this subject were so strong that he disregarded gossip, especially one that linked his critique of the statutes with a possible converso background. Valdés's aim was clear: to connect the two "hemispheres of the Republic," one earthly and the other spiritual, which were damaged by the same body of law-the statutes of purity of blood. He acknowledged that such measures might have been necessary at the end of the fifteenth century, but at the time of his writing, he insisted, the statutes were contrarie, or "morally impossible." In short, it was necessary to abolish the statutes because "an unjust law is not a law" (Lex iniusta non est lex). Valdés affirmed that this issue was the purview of the king, who had the moral and political responsibility to revoke any harmful law. ${ }^{32}$

In terms of temporal goals, the Memorial of Fernando de Valdés swung between a possible present, in which the statutes would be circumscribed, and a utopian future, in which they would be abrogated. Valdés's arguments, which were a mélange of arbitrista pragmatic ideas and utopian projects, were probably delivered into Olivares's hands. For this reason, the pragmatic and reformist part of Valdés's supplication promoted the main agenda of the Junta de Reformación (Board for reform). This institution, created by Olivares in 1621, stipulated that if there was proof of purity of blood for a family branch for three generations, the supplicant could secure a "pure" status in perpetuity.

30 Benjamin Hill and Henrik Lagerlund, eds., The Philosophy of Francisco Suárez (Oxford: Oxford University Press, 2012), 1-20. On Suárez's philosophy, law, and political thought, see Robert Aleksander Maryks and Juan Antonio Senent de Frutos, eds., Francisco Suárez (15481617): Jesuits and the Complexities of Modernity (Leiden: Brill, 2019).

$31 \quad$ Joseph Munitiz, "Francisco Suárez and the Exclusion of Men of Jewish and Moorish Descent from the Society of Jesus," Archivum historicum Societatis Iesu 73 (2004): 327-40.

$3^{2}$ Memorial de Fernando de Valdés..., fols. $13^{\mathrm{r}}-14^{\mathrm{r}}, 30^{\mathrm{r}}$. 
Nonetheless, Valdés envisioned an idyllic future in which the statutes would be abolished wholesale, after which many positive consequences would follow "for common and particular goods, for soul and body, for faith and religion, for peace and joining together, for finances and honor, for increasing people's number, for valor, for culture, for ministries, for fidelity and love to the king." ${ }^{33}$

The utopian element in the Memorial, however, was not confined to the goal of a Spanish monarchy rid of its purity of blood statutes, but also included a controversial social issue: Old Christians' social supremacy and authority. In this work, Valdés argued vigorously against the discrimination experienced by New Christians that he perceived as obstructing the development of the Christian republic. With this aim, he made two optimistic and novel assertions: most of the New Christians were sincere in their Christianity; and they had a set of virtues that would be useful for reviving a monarchy that had been disabled by a deep decadence, partly because of matters of blood.

\section{Conversos, Sincere Christians, and Guides of a New Age}

As with any utopian vision, Valdés's reflections pivot on the issue of timing. ${ }^{34}$ These reflections were presented as closely connected to the time of Philip IV (to whom the supplication was addressed) and Olivares (who was probably the main intermediary between the author of the Memorial and the addressee) in order to reform a society in crisis and relieve the sick body of the monarchy. This new and reformed time had to go hand in hand with a new sort of man, whose essential obligation is to be a "good and sincere Christian, regardless of his blood." This "note about the blood and the origins" summarized Valdés's critique of one of the most important injustices of his time: the lamentable condition of marginalization and exclusion in which conversos lived. Valdés was not only aware of this, but also wanted to assume an active role in its solution, requesting the abrogation of the statutes of purity of blood within the monarchy that were the primary cause of the conversos' situation. ${ }^{35}$ As part of his polemic, he painted an idyllic portrait of the New Christians.

33 Memorial de Fernando de Valdés..., fol. $26^{\mathrm{v}}$.

34 Karl Mannheim, Ideology and Utopia: An Introduction to the Sociology of Knowledge (London: Routledge \& Kegan Paul, 1936).

35 Antonio Possevino (1533-1611), together with Mariana, Ribadeneyra, Guzmán, and Girón Alarcón were among the Jesuits who expressed a firm opposition to the establishment of the statutes within the Society (Maryks, Jesuit Order as a Synagogue of Jews, 182-213). Regarding previous initiatives to oppose or limit converso integration within Iberian society, 
It is worth mentioning that Valdés's forceful argument in favor of conversos did not always include all converted Christians and their descendants. Although Valdés maintained that the Catholic faith is a "purifying virtue" and is equally valid for those who were converted "a long time ago or a few days ago," moriscos and Portuguese New Christians - or marranos - were excluded from this radical endorsement. Valdés was suspicious of them; he doubted their faith and religious practices and behavior. Only a select group, consisting of families that had converted before the sixteenth century, fully enjoyed Valdés's defense. These were Jews who had converted to Christianity in the Iberian kingdoms throughout the fifteenth century, including in 1492, when the decree to expel the Jews was promulgated. Only after 150 years of living as baptized Christians could they be considered sincere Christians, Valdés reasoned, because of the manner in which they practiced religion, their habits, and their lifestyle. Among the more reliable group of conversos, Valdes calculated, at least six generations had settled and cleared the stain of their lineage, proving their true embrace of Catholicism. Thus, Valdés dismissed the suspicion that such conversos were not loyal, devoted, and honest:

Today in Spain, once Jews and Moors were expelled and once the violent conversions were mitigated, conversos are commonly known as safe Christians because of their Catholic profession and habits. There is little doubt that lineage does not vouch for a better job or service; the benefit that we call Old Christian does not make someone better than one who is not so old. There is no reason to take precautions to avoid contagion by others. ${ }^{36}$

Through his vision of these conversos, Valdés drew an image of a new man who was primarily defined by his fame and reputation. The blemish of lineage, which the society of Old Christians and the statutes of the purity of blood insisted on remembering, bypassed those skilled New Christians who, in Valdés's view, could be considered irreproachable, with impeccable customs and "known as good as the best." ${ }^{\prime 3}$ Therefore, Valdés's main goal was New Christians' complete assimilation. He presented a set of arguments, experiences, and certainties that he linked with the past, present, and future. He proposed to fight against the

see Claude B. Stuczynski, "Harmonizing Identities: The Problem of the Integration of the Portuguese Conversos in Early Modern Iberian Corporate Polities," Jewish History 25 (2011): 229-57.

36 Memorial de Fernando de Valdés..., fol. $14^{\mathrm{v}}$.

37 Memorial de Fernando de Valdés..., fol. $30^{\mathrm{v}}$. 
stigma of conversos as direct descendants of Jews, who had been scapegoated for social and political conflict during the fourteenth and fifteenth centuries. ${ }^{38}$ That time was past. It was for this reason that Valdés highlighted, first and foremost, the present. Opposing this past view of conversos, he argued that this specific category of New Christians was in the 1630 s "quiet, pacific, and truly faithful" - and true Catholics, as Valdés reiterated time and again. The main harm of the statutes, then, was that they separated and removed many "good religious and Ministers of Gospel" from the church, who could otherwise ennoble and elevate the monarchy and the religious community.

Based on this premise- that most of the Spanish conversos were sincere Christians-Valdés combined a severe critique of the society in which he lived with ideas that formed the foundation of his social project. Valdés's supplication, radical for its time, not only concerned the New Christians, but was also a profound reappraisal of Old Christians' social, political, and cultural hegemony. ${ }^{39}$ Society was broken because of the statutes, he lamented; they defined the superiority of those who were the heirs of Old Christians. Valdés knew that he was on dangerous ground here, edging toward a shattering of the existing social order. He therefore focused his critique on the absurdity of the distinction between Old and New Christians. In this regard, he took special issue with a prevailing argument about conversos' descendants: that they were predisposed to leave the true faith and practice. ${ }^{40}$

In Valdés's efforts to integrate the conversos into a society inspired by the primitive meaning of the church, he paraphrased Paul's Epistle to the Ephesians (Ephesians 4:4-6): "one mystic body [...], one exhilarating spirit, one vocation, one God, one Father for everybody, one faith and one baptism.".41 On this point, Valdés simply was following an approach that had been used since the fifteenth century, that is, Pauline theology as the axis of critiques against purity of blood statutes. ${ }^{42}$ Even so, more relevant in Valdés's Memorial than the sources he employed was how he interpreted and reoriented them in

38 Bruce Rosenstock, New Men: Conversos, Christian Theology, and Society in Fifteenth-Century Castile (London: Queen Mary and Westfield College, 2002).

39 Arlette Jouanna, La idée de race en France au XVIe siècle et au début du XVIIe siècle (Lille: Université de Lille III, 1976).

$40 \quad$ Memorial de Fernando de Valdés..., fol. $15^{\mathrm{r}}$.

41 Memorial de Fernando de Valdés..., fol. $6^{v}$.

42 Claude B. Stuczynski, "Pro-converso Apologetics and Biblical Exegesis," in The Hebrew Bible in Fifteenth-Century Spain: Exegesis, Literature, Philosophy, and the Arts, ed. Jonathan Decter and Arturo Prats (Leiden: Brill, 2012), 151-76; Stuczynski, "From Polemics and Apologetics to Theology and Politics: Alonso de Cartagena and the Conversos within the 'Mystical Body," in 
order to reach his objective. Paul's ideas, ${ }^{43}$ for instance, recurred repeatedly, in his calls to establish a Christian community that was neither broken nor divided: "Saint Paul is tireless when he persuades in favor of the union, the approval and the equality among Christians." ${ }^{44}$ On the basis of Paul's views on the religious community, Valdés extrapolated a set of ideas for the political community, especially the monarchy. According to Paul, Valdés explained, everybody can be Christian, and there should be no difference among the faithful, whether age-old Christians or those converted after 1492. Thus, there was no reason to prevent conversos from becoming the king's true vassals; it was not reasonable to refuse them the opportunity to serve the institutions of the monarchy. In short, Valdés made of King Philip IV the daring request that "all his subjects become pure and Old Christians." 45

Valdés made no distinction between the king's vassals, placing them all on the same level. Such an avoidance of differentiation on the basis of race, blood, or origin led to the necessity of presenting his position's positive political impact in his discourse. Valdés worried about the statutes' hazardous effects on the church, and especially on the monarchy. Numerous New Christians were excluded from honors, professions, offices, benefits, and posts; "those who are classified as Old Christian, are neither adequately trained for their ministry, commonly speaking, nor were hard-working when they had to serve the Republic." ${ }^{\prime 6}$ Taking a pragmatic tone, Valdés even claimed that the statutes had at one time been necessary for the security of faith and the good distribution of honors and offices. Nevertheless, he claimed, it was no longer reasonable to maintain the law of purity of blood.

To support his argument, Valdés presented a portrait of the conversos as sincere Christians, with excellent customs and possessing talents and virtues:

When one occupies a position, it is less important the quality of being Old Christian than the individual talents of customs, virtues and, training. Because they [Old Christians] are not better, nor more meritorious, they are not distinguished by their diligence and care. ${ }^{47}$

Conflict and Religious Conversation in Latin Christendom: Studies in Honour of Ora Limor, ed. Israel Jacob Yuval and Ram Ben-Shalom (Turnhout: Brepols, 2014), 253-75. Jordi Sánchez Bosch, Maestro de los Pueblos: Una teología de Pablo, el apóstol (Estella: Verbo Divino, 2007), 316-21; Claudio Basevi, Introducción a los escritos de san Pablo: Su vida y su teología (Madrid: Ediciones Palabra, 2013), 137-38.

44 Memorial de Fernando de Valdés..., fol. $12^{\mathrm{r}}$.

45 Memorial de Fernando de Valdés..., fol. $26^{\mathrm{r}}$.

46 Memorial de Fernando de Valdés..., fol. $21^{\mathrm{r}}$.

47 Memorial de Fernando de Valdés..., fol. $18^{\mathrm{v}}$. 


\section{New Values and Valdés's Project for Spanish Society}

The exceptional feature of the Memorial is the interest Valdés inspires as a leading actor in the debate about statutes of purity of blood. He knew that his proposal had the support of prominent past and present members of the intellectual elite, including the Hieronymite Superior General Alonso de Oropesa, the Franciscan Henri Mauroy (?-1570), ${ }^{48}$ the canonist and theologian Martín de Azpilcueta (1491-1586), cardinals Gaspar de Quiroga (1512-94), Fernando Niño de Guevara (1541-16o9), Bernardino Sandoval y Rojas (1546-1618), and the bishop Andrés Pacheco (1550-1626). Nonetheless, it was also abundantly clear that he was confronting a society that encouraged the perpetuation of the statutes of purity of blood, along with the divisions created by these statutes. Perhaps the greatest adversary that Valdés faced in his project of reform was Bartolomé Ximénez de Patón (1596-1640), a notary of the Inquisition and a professor of Latin. ${ }^{49}$ In 1638, Patón wrote and published a work that appeared to be a direct response to Valdés's project. ${ }^{50}$ Patón referred to the Jesuit's arguments as "imprudence" and "insolence," and claimed that New Christians could never be seen as sincere Christians. ${ }^{51}$ Patón's own experiences as a member of the Inquisition allowed him to state that conversos had "something crying out in their hearings and hearts for falling into the vice of unfaithfulness that comes from their progenitors and that is deeply rooted, for it seems they inherit it." 52

Valdés was well aware that a social majority backed Patón's discourse on the application of the statute. Thus, he deployed a systematic reply against the Old Christians' mentality by suggesting the abrogation of the statutes and, at the same time, proposing a radical revision of what New Christians could contribute to society and the monarchy. Valdés acknowledged that the statutes had a

48 Henri Mauroy, Apologia in duas partes divisa... (Paris: Vivantium Gaultherot, 1553).

49 María del Carmen Bosch et al., BartoloméJiménez Patón: Comentarios de erudición (Madrid: CSIC, 2010); Jaume Garau, “No hay mayor desigualdad que hacerlo todo igual': Sobre el Discurso de Bartolomé Jiménez Patón en defensa de los estatutos de limpieza," Bulletin hispanique 114 (2012): 597-620; Jaume Garau, "Ideas religiosas del Maestro Bartolomé Jiménez Patón (1569-1640) en El virtuoso discreto (c.1629-1631)," Hispania sacra 129 (2012): $237-58$.

Biblioteca Nacional de España (BNE), USo7, 9813, Discurso en favor del Santo y Loable Estatuto de Limpieza de Sangre, por el Maestro Bartolomé Ximenez de Paton..., 1638 [henceforth, Discurso en favor...].

51 François Soyer, "It Is Possible to Be Both a Jew and a Christian: Converso Religious Identity and the Inquisitorial Trial of Custodio Nunes (1604-5)," Mediterranean Historical Review 26 (2011): 81-97.

$5^{2}$ Discurso en favor..., fol. $4^{\mathrm{r}}$. 
raison d'être when they were promulgated at the end of the fifteenth century; during those years, there was suspicion that the recent conversos' faith was weak and changeable. Thus, it had been important to establish various laws of purity of blood. But, arguing that more than a reasonable amount of time had passed since then, Valdés highlighted a number of unjust effects and unreasonable consequences of the statutes: "the statutes honor, hire, and reward a low man, although with the title of 'pure,' and those who are really distinguished and meritorious are taken down and put aside." 53

Valdés not only tried to correct the statutes' harmful effects, but also outlined the essential vectors of a social project, which he firmly believed would improve the religious and political community as a whole. He remarked constantly that the worst consequences of the statutes had been that several illustrious New Christians were excluded from honors and offices. For this reason, "the Republic is short of good Ministers." ${ }^{54}$ On this point, it is possible to see how Valdés's interests went hand in hand with Olivares's political program, which had, as one of the most relevant requisites, a search for new officers and administrators for the crown. ${ }^{55}$ Although the set of measures that Valdés and Olivares proposed seem reformist in nature, they were in fact even more far-reaching and innovative. In fact, their plans could have shaken the monarchy's framework of power, ${ }^{56}$ as removing the statutes was tantamount to changing the social groups upon which the monarchy was built. Valdés's intention was not to exclude the nobility and Old Christians, but to integrate a new nobility of merit, including conversos. Thus, by referring to the changing times and pointing out the monarchy's predicaments, he could more safely dare to question the Old Christians' monopoly on power.

In the present time, and in the current state of our nation [...] it is not reasonable to doubt $[\ldots]$ those that have the best talents and excellent customs are not the so-called Old Christians. And those other [New Christians] are not less constant and firm in Faith than Old Christians. Nobody can doubt it; this is morally true by natural reason, by experience, and by authority. ${ }^{57}$

53 Memorial de Fernando de Valdés..., fol. $21^{\mathrm{v}}$.

54 Memorial de Fernando de Valdés..., fol. $3^{\mathrm{r}}$.

55 Juan I. Gutiérrez Nieto, "El reformismo social de Olivares: El problema de la limpieza de sangre y la creación de una nobleza de mérito," in La España del Conde Duque de Olivares, ed. John H. Elliott and Ángel García Sanz (Valladolid: Universidad de Valladolid, 199o), 417-41.

56 Jean Pierre Dedieu, "Limpieza, poder y riqueza: Requisitos para ser ministro de la Inquisición, Tribunal de Toledo, siglos XVI-XVII," Cuadernos de historia moderna 14 (1993): 29-44.

Memorial de Fernando de Valdés..., fol. $15^{\mathrm{r}}$. 
Valdés questioned the social order and, at the same time, endeavored to solidify the pillars of his social project. He repudiated the situation that his society had reached; the statutes had inverted their original function and become insurmountable walls. Social groups and institutions had become hermetic, creating the image of a society divided into rigid and lifeless compartments. This picture fits with Patón's demand to "close the door on them [New Christians]" and "to hit them in the face," 58 "to close the door not only under lock and key, but also seal them hermetically with molten bronze."59

Valdés did not propose an egalitarian social project. He imagined a new structure with a utopian inspiration, though never totally beyond reality; he did not cast aside the inevitable barriers. Firstly, and as a prerequisite, the office of any public minister, especially an ecclesiastical one, had to be occupied by someone who was considered a sincere Christian. Valdés did not forget that the order of estates was the principal structure and fundamental organization of society at the time. For this reason, his critique did not challenge this order, though he did not hide a certain resignation: "There is enough distinction and subordination through the separation between nobles and plebeian." 60 However, he accepted that other nations in Europe made the same differentiation - that "other Republics and nations support and supported this." ${ }^{1}$

Another challenging aspect of the statues was the differentiation that they created and the social pre-eminence that was accorded to Old Christians. Valdés reassured his harsher critics when he said that if there was an old nobility, and another one that was newer, it would be necessary to respect the merit of being Christian for a longer amount of time. In fact, Valdés did not believe New Christians should be accorded the same status as Old Christians. He did not intend to eliminate the social order and its rigid compartmentalization; he only tried to erase the infamy implicit in being a converso.

If the framework of his project could be defined as reformist, the heart of the proposal was utopian in nature. Valdés ultimately wished that the social hierarchies generated by the statutes of purity of blood would be dismantled. Thus, once everyone could be considered a sincere Christian, the attainment of offices would be grounded on personal criteria alone:

The statutes $[\ldots]$ created and preserved inequality among those who are equally good Christians, just because they were older or newer

\footnotetext{
$5^{8}$ Discurso en favor..., fol. $1^{\mathrm{r}}$.

59 Discurso en favor..., fol. $7^{\mathrm{r}}$.

6o Memorial de Fernando de Valdés..., fols. $3 \mathrm{O}^{\mathrm{v}}-31^{\mathrm{r}}$.

$61 \quad$ Memorial de Fernando de Valdés..., fols. $3 \mathrm{O}^{\mathrm{v}}-31^{\mathrm{r}}$.
} 
Christians [...]. If we are good and we are equal in this part, is it a problem? If it is an ailment, Heaven suffers it, since there everybody is good, without blemish nor stain. Would there be enough distinction if we only consider individual talents and merits? This should be our ultimate aim, and we should imitate who gave to everyone a blank shield, in which could be engraved the insignia and emblems that they deserve by their own behavior. ${ }^{62}$

This allegory of "blank shields" suggests that Valdés dreamt of a society where each person would be valued on their own personal merits. The basic requirement that he proposed was an examination of customs and habits. In his idyllic portrait of conversos, Valdés argued not only that they were qualified for offices, posts, and jobs, but that they were also guides to proper behavior, unlike many hypocritical Old Christians. The latter "pay more attention to their ancient condition, than to being sincere Christians in their present habits." 63 Valdés applied the behavior-based model for evaluation as a human being to the converso, replacing the determinism of race with a novel criterion for social stratification: "The only thing that matters is personal habits, because the most important element is the purity and the nobility that originates by and for Christ, without paying heed to other lineages or origins."64

As the conversos had not been incorporated into the social order as full-fledged subjects, Valdés understood why they often chose to refrain from taking part in any important undertaking or endeavor of the monarchy. Their efforts were always blocked by the demand for proofs of purity of blood, which generally caused them public shame. According to Valdés, in the new era that was dawning, and in a monarchy that needed the best men, it was not acceptable to maintain laws that encouraged faintheartedness among vassals. If the statutes were revoked, society would experience a positive synergy, in which the conversos' fresh enthusiasm for the faith would serve as a springboard for Old Christians' religiosity. Therefore, everybody should be equipped with a blank shield, upon which one could sculpt, throughout his life, the figures and blazons that he deserved: "The truth is that personal talent and individual virtues ennoble, and everybody can aspire to attain this." 65

\footnotetext{
62 Memorial de Fernando de Valdés..., fol. $30^{\mathrm{v}}$.

63 Memorial de Fernando de Valdés..., fol. $19^{\mathrm{r}}$.

64 Memorial de Fernando de Valdés..., fol. $9^{\mathrm{v}}$. See Max S. Hering Torres, María Elena Martínez, and David Niremberg, eds., Race and Blood in the Iberian World (Berlin: Lit Verlag, 2012).

65 Memorial de Fernando de Valdés..., fol. $15^{\mathrm{r}}$.
} 
Valdés's Memorial was exceptional as much for what was openly requested - the abrogation of the statutes — as for what its wording demurely implied. The Memorial argued that the once-reviled New Christian harbored a new and alternative vision for Spain $^{66}$ that could extricate Spanish society and the Spanish monarchy from the "moment of crisis" it was enduring. ${ }^{67}$ Furthermore, Valdés's writing uniquely encompassed a discourse (at once attractive and confusing) about what was possible in a dreamed-of utopia:

I only say that if one understands and carries out that there would be reward in proportion to achievement, without any stain of lineage, it would be an infinite breath for Spanish spirits; since they would work and would take advantage of it in culture, warfare, and politics. This state would be undoubtedly a consequence of the abrogation of the statutes. It would be an invention or a discovery of a great treasure, richer and more powerful than all gold and precious stones. ${ }^{68}$

\section{Conclusions}

The Memorial sent by Valdés to Philip IV in the first third of the seventeenth century, which simultaneously proposed the limitation and all-out suppression of the statutes of purity of blood, was unique in its claims and ambition. What at first glance could be seen as a contradiction between a pragmatic solution and a utopian dream in fact stemmed from an inner dialectical tension. In addition to the evidence he cited from numerous writings addressed against these exclusionary laws, Valdés highlighted the spirit of a "union of hearts," espoused by Loyola as well as many other Spanish Jesuits. We may mention two particular influences: the moral theology of Suárez and Paul's idea of universalism. Valdés's stance could be considered utopian because, in the period in which he lived, purity of blood was a central pillar of the social structure. Only a social minority, united around the king's favorite, showed an interest in its reform; however, Valdés went beyond this and sought the complete abrogation of the statutes.

66 See Francisco Márquez Villanueva's introductory comments in Antonio Domínguez Ortiz, La clase social de los conversos en Castilla en la Edad Moderna (Granada: Universidad de Granada, 1991), ix-xxiv.

67 Pablo Fernández Albaladejo, La crisis de la Monarquía (Barcelona: Crítica; Marcial Pons, 2009).

68 Memorial de Fernando de Valdés..., fol. $\mathbf{2 2}^{\mathrm{v}}$. 
One of the most innovative elements of Valdés's Memorial was the portrait he painted of New Christians. In this portrayal, they were just as suited as Old Christians to perform the main offices in the institutions of the monarchy. Valdés aimed to remedy the social exclusion and lack of respect with which conversos struggled. Thus, he supported the project of the monarchy, led by Olivares, to reassess the existing social order, endorsing the idea that talent and personal virtues should not be subjugated to lineage and legacy of blood. Had the social model of Valdés won widespread support, the outcome would have been a renewed society that prized not only ancestral virtues, but individual ones as well. 